\title{
Crystal Structure of a Novel One-dimensional Chain Compound Formed by Zinc(II) and Imino Nitroxide Radicals
}

\author{
Liya WANG, ${ }^{* \dagger}$ Yufang WANG ${ }^{* *}$, Lufang MA, ${ }^{*}$ and Kai JIANG** \\ *Department of Chemistry, Luoyang Teacher's College, Luoyang 471022, P. R. China \\ **College of Chemistry and Environmental Science, Henan Normal University, Xinxiang 453002, P. R. China
}

\begin{abstract}
The structure of novel complex formed by zinc(II) and imino nitroxides of formula $\left[\mathrm{Zn}(\mathrm{IM} 2-\mathrm{Py})_{2}\left(\mathrm{NO}_{3}\right)\right] \cdot\left(\mathrm{NO}_{3}\right)(\mathrm{IM} 2-\mathrm{Py}=$ 2-(2'-pyridyl)-4,4,5,5-tetramethylimidazoline-1-oxyl) was determined by the X-ray diffraction method. The compound crystallizes in orthorhombic, space group $P 2{ }_{1} 2_{1} 2_{1}$ with $a=11.026(2), b=13.575(3), c=20.435(4) \AA, V=3058.6(11) \AA^{3}, Z$ $=4$. The final $R$ value is 0.0565 for 2637 reflections $(I>2 \sigma(I))$. X-ray analysis reveals that the crystal structure consists of $\left[\mathrm{Zn}(\mathrm{IM} 2-\mathrm{Py})_{2}\left(\mathrm{NO}_{3}\right)\right]^{+}$moiety and a $\mathrm{NO}_{3}{ }^{-}$anion. The zinc(II) ion is six-coordinated with a distorted octahedral geometry. The units of $\left[\mathrm{Zn}(\mathrm{IM} 2-\mathrm{Py})_{2}\left(\mathrm{NO}_{3}\right)\right]^{+}$and $\mathrm{NO}_{3}{ }^{-}$anions were connected as a one-dimensional chain compound by the intermolecular interaction.
\end{abstract}

(Received November 29, 2004; Accepted April 26, 2005; Published on web July 8, 2005)

The design and synthesis of molecule-based magnetic materials is one of the major subjects of materials science. Nitronyl nitroxide radicals (NITR), stable organic radicals, have played a prominent role in the design and construction of molecular magnetic materials. ${ }^{1,2}$ The "metal-organic" strategy of combining organic radicals with paramagnetic transition metal has been particularly successful, and a wide variety of species utilizing nitronyl nitroxides as ligands have been described. ${ }^{3}$ However, the reports of the diamagnetic metal ions with radicals are much fewer than those of the paramagnetic metal

Table 1 Crystal and experimental data

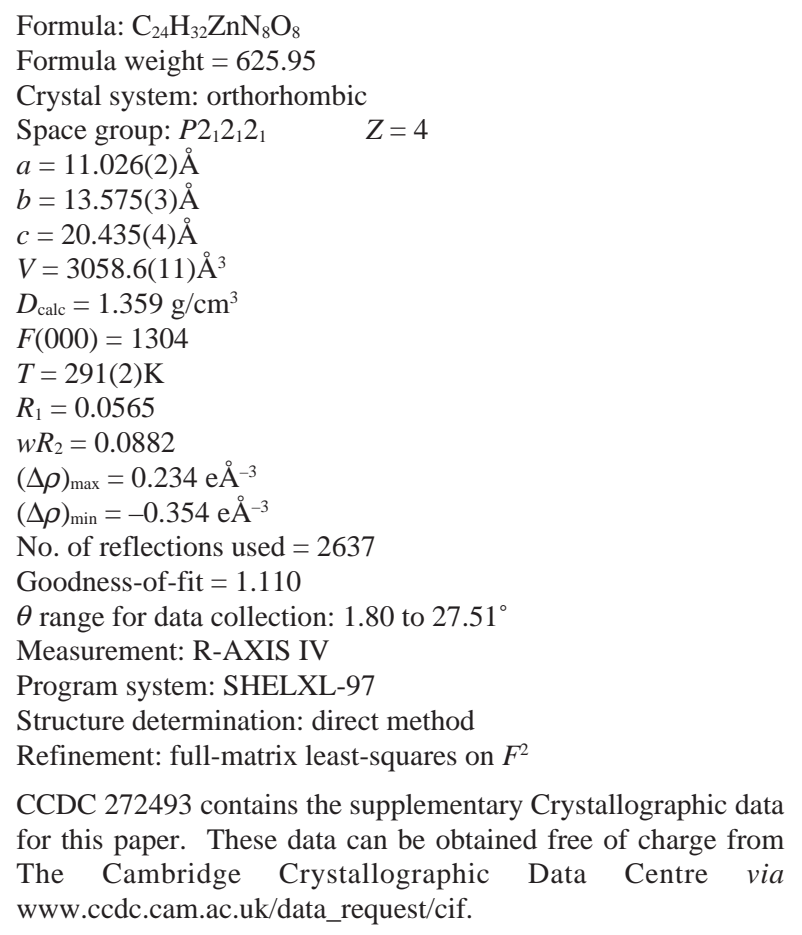

To whom correspondence should be addressed.

E-mail: wly@lync.edu.cn ions with radicals. In the present work, we have obtained a novel one-dimensional chain structure complex [Zn(IM2$\left.\mathrm{Py})_{2}\left(\mathrm{NO}_{3}\right)\right] \cdot\left(\mathrm{NO}_{3}\right)(\mathrm{IM} 2-\mathrm{Py}=2$-(2'-pyridyl)-4,4,5,5-tetramethylimidazoline-1-oxyl). We report herein on the synthesis and crystal structure of this new complex.

IM2-Py was prepared by a literature method. ${ }^{4}$ The complex $\left[\mathrm{Zn}(\mathrm{IM} 2-\mathrm{Py})_{2}\left(\mathrm{NO}_{3}\right)\right] \cdot\left(\mathrm{NO}_{3}\right)$ was synthesized by the addition of IM2-Py $(0.055 \mathrm{~g}, 0.25 \mathrm{mmol})$ to a $20 \mathrm{~mL}$ ethanol solution of $\mathrm{Zn}\left(\mathrm{NO}_{3}\right)_{2} \cdot 6 \mathrm{H}_{2} \mathrm{O}(0.037 \mathrm{~g}, 0.125 \mathrm{mmol})$. The mixture was stirred for $4 \mathrm{~h}$ and then filtered; the clear red filtrate was diffused with diethyl ether vapor at room temperature. Red crystals formed and were collected by filtration and dried in air.

The X-ray data were collected on a diffractometer equipped with graphite-monochromated Mo $K_{\alpha}$ radiation $(\lambda=0.71073 \AA)$ at 291(2)K. The structure was solved by direct methods and refined by full-matrix least-squares techniques on $F^{2}$ with the program SHELXTL-97. All of the non-hydrogen atoms were refined anisotropically. The hydrogen atoms were assigned with common isotropic displacement factors and were included in the final refinement by using geometrical restrains. The final agreement factor value was $R=0.0565$. The results of an X-ray structure determination are given in Tables $1-3$.

A chemical diagram is shown in Fig. 1 and the structure is shown in Figs. 2 - 3. The crystal structure consists of unit of $\left[\mathrm{Zn}(\mathrm{IM} 2-\mathrm{Py})_{2}\left(\mathrm{NO}_{3}\right)\right]^{+}$moiety and an uncoordinated $\mathrm{NO}_{3}{ }^{-}$anion. In the complex, the coordination geometry about the zinc(II) ion is an distorted octahedral characterized by the chelation of two IM2-Py ligands through the pyridyl nitrogen and imino

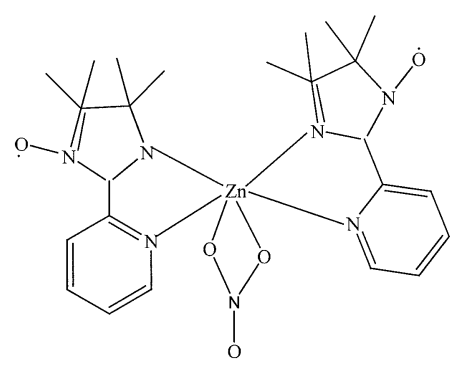

Fig. 1 Chemical diagram of $\left[\mathrm{Zn}(\mathrm{IM} 2-\mathrm{Py})_{2}\left(\mathrm{NO}_{3}\right)\right]^{+}$. 
Table 2 Atomic coordinates and equivalent isotropic displacement parameters $\left(\AA^{2}\right)$ for the non-hydrogen atoms

\begin{tabular}{|c|c|c|c|c|}
\hline Atom & $x$ & $y$ & $z$ & $U_{\text {eq }}$ \\
\hline $\mathrm{Znl}$ & $0.31144(5)$ & $0.99664(4)$ & $0.81318(3)$ & $0.0431(2)$ \\
\hline N1 & $0.1510(4)$ & $1.0894(3)$ & $0.8103(2)$ & $0.0440(12)$ \\
\hline $\mathrm{N} 2$ & $0.3266(4)$ & $1.2645(3)$ & $0.9097(2)$ & $0.0410(16)$ \\
\hline N3 & $0.3687(4)$ & $1.1188(3)$ & $0.8647(2)$ & $0.0417(14)$ \\
\hline $\mathrm{N} 4$ & $0.4703(4)$ & $0.9043(3)$ & $0.8069(2)$ & $0.0447(14)$ \\
\hline N5 & $0.3120(4)$ & $0.7395(3)$ & $0.9195(2)$ & $0.0417(16)$ \\
\hline N6 & $0.2708(4)$ & $0.8863(3)$ & $0.8784(2)$ & $0.0400(14)$ \\
\hline N7 & $0.2830(5)$ & $0.9676(4)$ & $0.6841(3)$ & $0.0683(19)$ \\
\hline N8 & $0.7561(5)$ & $1.0246(4)$ & $0.6488(3)$ & $0.065(2)$ \\
\hline O1 & $0.2403(3)$ & $1.3215(3)$ & $0.94364(19)$ & $0.0587(14)$ \\
\hline $\mathrm{O} 2$ & $0.3971(3)$ & $0.6723(2)$ & $0.94492(18)$ & $0.0520(14)$ \\
\hline $\mathrm{O} 3$ & $0.2330(4)$ & $0.9114(3)$ & $0.7242(2)$ & $0.0730(17)$ \\
\hline $\mathrm{O} 4$ & $0.2716(6)$ & $0.9585(4)$ & $0.6259(2)$ & $0.129(3)$ \\
\hline O5 & $0.3463(4)$ & $1.0360(3)$ & $0.7089(2)$ & $0.0707(16)$ \\
\hline O6 & $0.7107(4)$ & $1.0868(3)$ & $0.6862(2)$ & $0.0830(17)$ \\
\hline O7 & $0.7037(4)$ & $1.0037(3)$ & $0.5955(2)$ & $0.0821(15)$ \\
\hline O8 & $0.8519(4)$ & $0.9806(4)$ & $0.6630(3)$ & $0.101(2)$ \\
\hline $\mathrm{C} 1$ & $0.0469(5)$ & $1.0724(4)$ & $0.7790(3)$ & $0.0540(19)$ \\
\hline $\mathrm{C} 2$ & $-0.0486(5)$ & $1.1402(4)$ & $0.7793(3)$ & $0.061(2)$ \\
\hline $\mathrm{C} 3$ & $-0.0316(5)$ & $1.2285(4)$ & $0.8105(3)$ & $0.062(2)$ \\
\hline $\mathrm{C} 4$ & $0.0766(5)$ & $1.2484(4)$ & $0.8423(3)$ & $0.0473(17)$ \\
\hline $\mathrm{C} 5$ & $0.1661(4)$ & $1.1774(3)$ & $0.8420(2)$ & $0.0360(16)$ \\
\hline C6 & $0.2875(5)$ & $1.1861(3)$ & $0.8729(2)$ & $0.0360(16)$ \\
\hline $\mathrm{C} 7$ & $0.4325(5)$ & $1.2302(4)$ & $0.9487(3)$ & $0.0500(19)$ \\
\hline $\mathrm{C} 8$ & $0.4824(5)$ & $1.1521(4)$ & $0.8988(3)$ & $0.0487(19)$ \\
\hline C9 & $0.3851(6)$ & $1.1806(5)$ & $1.0111(3)$ & $0.070(3)$ \\
\hline $\mathrm{C} 10$ & $0.5148(5)$ & $1.3153(4)$ & $0.9658(3)$ & $0.066(3)$ \\
\hline $\mathrm{C} 11$ & $0.5632(6)$ & $1.1995(5)$ & $0.8460(3)$ & $0.070(3)$ \\
\hline $\mathrm{C} 12$ & $0.5491(6)$ & $1.0659(5)$ & $0.9299(3)$ & $0.079(3)$ \\
\hline $\mathrm{C} 13$ & $0.5688(5)$ & $0.9201(4)$ & $0.7713(3)$ & $0.056(2)$ \\
\hline $\mathrm{C} 14$ & $0.6648(5)$ & $0.8540(4)$ & $0.7684(3)$ & $0.061(2)$ \\
\hline $\mathrm{C} 15$ & $0.6522(5)$ & $0.7662(4)$ & $0.8010(3)$ & $0.059(2)$ \\
\hline C16 & $0.5487(5)$ & $0.7480(4)$ & $0.8373(3)$ & $0.0463(17)$ \\
\hline $\mathrm{C} 17$ & $0.4608(4)$ & $0.8197(4)$ & $0.8407(3)$ & $0.0400(17)$ \\
\hline $\mathrm{C} 18$ & $0.3477(5)$ & $0.8151(4)$ & $0.8806(3)$ & $0.0373(17)$ \\
\hline $\mathrm{C} 19$ & $0.2170(5)$ & $0.7774(4)$ & $0.9650(3)$ & $0.0447(17)$ \\
\hline $\mathrm{C} 20$ & $0.1624(4)$ & $0.8581(4)$ & $0.9183(3)$ & $0.0443(17)$ \\
\hline $\mathrm{C} 21$ & $0.1326(5)$ & $0.6941(4)$ & $0.9839(3)$ & $0.065(2)$ \\
\hline $\mathrm{C} 22$ & $0.2781(5)$ & $0.8206(5)$ & $1.0250(3)$ & $0.064(2)$ \\
\hline $\mathrm{C} 23$ & $0.0688(5)$ & $0.8156(5)$ & $0.8706(3)$ & $0.068(3)$ \\
\hline $\mathrm{C} 24$ & $0.1109(6)$ & $0.9468(4)$ & $0.9535(3)$ & $0.066(2)$ \\
\hline
\end{tabular}

$U_{\text {eq }}$ is defined as one third of the trace of the orthogonalized $U_{\mathrm{ij}}$ tensor.

Table 3 Selected bond distances $(\AA)$ and angles $\left(^{\circ}\right)$

\begin{tabular}{cccc}
\hline $\mathrm{Zn}(1)-\mathrm{N}(6)$ & $2.055(3)$ & $\mathrm{Zn}(1)-\mathrm{O}(3)$ & $2.318(3)$ \\
$\mathrm{Zn}(1)-\mathrm{N}(3)$ & $2.065(3)$ & $\mathrm{N}(2)-\mathrm{O}(1)$ & $1.411(4)$ \\
$\mathrm{Zn}(1)-\mathrm{N}(4)$ & $2.158(3)$ & $\mathrm{N}(5)-\mathrm{O}(2)$ & $1.409(4)$ \\
$\mathrm{Zn}(1)-\mathrm{N}(1)$ & $2.171(3)$ & $\mathrm{N}(7)-\mathrm{O}(3)$ & $1.242(5)$ \\
$\mathrm{Zn}(1)-\mathrm{O}(5)$ & $2.234(3)$ & $\mathrm{N}(7)-\mathrm{O}(5)$ & $86.75(13)$ \\
& & & \\
$\mathrm{N}(6)-\mathrm{Zn}(1)-\mathrm{N}(3)$ & $108.91(13)$ & $\mathrm{N}(4)-\mathrm{Zn}(1)-\mathrm{O}(5)$ & $88.57(13)$ \\
$\mathrm{N}(6)-\mathrm{Zn}(1)-\mathrm{N}(4)$ & $77.92(13)$ & $\mathrm{N}(1)-\mathrm{Zn}(1)-\mathrm{O}(5)$ & $93.53(13)$ \\
$\mathrm{N}(3)-\mathrm{Zn}(1)-\mathrm{N}(4)$ & $104.46(13)$ & $\mathrm{N}(6)-\mathrm{Zn}(1)-\mathrm{O}(3)$ & $156.03(13)$ \\
$\mathrm{N}(6)-\mathrm{Zn}(1)-\mathrm{N}(1)$ & $105.21(13)$ & $\mathrm{N}(3)-\mathrm{Zn}(1)-\mathrm{O}(3)$ & $88.03(12)$ \\
$\mathrm{N}(3)-\mathrm{Zn}(1)-\mathrm{N}(1)$ & $78.37(12)$ & $\mathrm{N}(4)-\mathrm{Zn}(1)-\mathrm{O}(3)$ & $87.89(12)$ \\
$\mathrm{N}(4)-\mathrm{Zn}(1)-\mathrm{N}(1)$ & $175.01(13)$ & $\mathrm{N}(1)-\mathrm{Zn}(1)-\mathrm{O}(3)$ & $55.63(12)$ \\
$\mathrm{N}(6)-\mathrm{Zn}(1)-\mathrm{O}(5)$ & $146.23(12)$ & $\mathrm{O}(5)-\mathrm{Zn}(1)-\mathrm{O}(3)$ & $115.6(4)$ \\
$\mathrm{N}(3)-\mathrm{Zn}(1)-\mathrm{O}(5)$ & $103.97(12)$ & $\mathrm{O}(4)-\mathrm{N}(7)-\mathrm{O}(3)$ & $123.4(5)$ \\
\hline
\end{tabular}

nitroxide nitrogen, leading to two five-membered rings together with one chelated nitrate anion ligand. The two oxygen atoms $(\mathrm{O} 3, \mathrm{O} 5)$ from the nitrate ligand and two nitrogen atoms $(\mathrm{N} 3$, N6) from two different IM2-Py radicals that comprise the equatorial plane, whereas the axial positions are filled by two nitrogen atoms $(\mathrm{N} 1, \mathrm{~N} 4)$ from different pyridyl rings. The bond

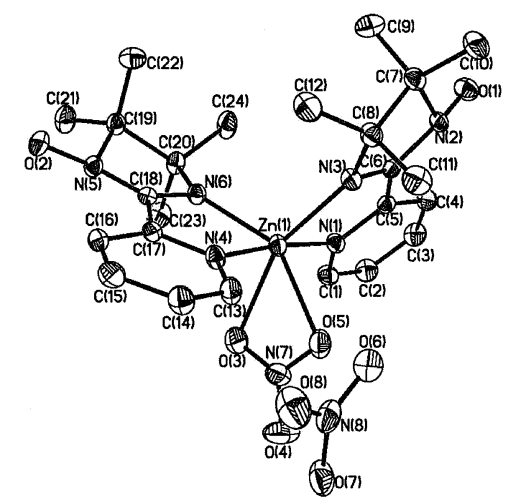

Fig. 2 Molecular structure of the $\mathrm{Zn}$ (II) complex.

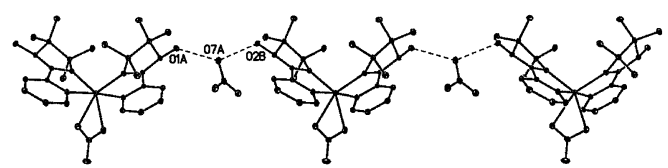

Fig. 3 A sketch of the intermolecular interaction of the $\mathrm{Zn}(\mathrm{II})$ complex.

lengths of $\mathrm{Zn}(1)-\mathrm{O}(3)$ and $\mathrm{Zn}(1)-\mathrm{O}(5)$ are 2.318(3) and 2.234(3) $\AA$, respectively. The bond lengths of the axial $\mathrm{Zn}-\mathrm{N}$ $(\mathrm{Zn}(1)-\mathrm{N}(1)=2.171(3) \AA$ and $\mathrm{Zn}(1)-\mathrm{N}(4)=2.158(3) \AA)$ are longer than those of the equatorial $\mathrm{Zn}-\mathrm{N}(\mathrm{Zn}(1)-\mathrm{N}(3)=$ $2.065(3) \AA$ and $\mathrm{Zn}(1)-\mathrm{N}(6)=2.055(3) \AA)$, which are in the normal range. ${ }^{5}$ The bond lengths of uncoordinated $\mathrm{N}-\mathrm{O}$ are $1.411(4) \AA$ and $1.409(4) \AA$ for $\mathrm{N}(2)-\mathrm{O}(1)$ and $\mathrm{N}(5)-\mathrm{O}(2)$, respectively. The distortion along the axial direction is demonstrated by the N1-Co1-N4 angle of 176.64(14) ${ }^{\circ}$.

There are significant intermolecular contacts in the structure of the complex. The intermolecular short contacts occur between one oxygen atom from the uncoordinated $\mathrm{NO}_{3}{ }^{-}$anion and two oxygen atoms of the NO groups of neighbor [Zn(IM2$\left.\mathrm{Py})_{2}\left(\mathrm{NO}_{3}\right)\right]^{+}$units $(2.682 \AA$ for $\mathrm{O} 1 \mathrm{~A} \cdots \mathrm{O} 8 \mathrm{~A}, 2.684 \AA$ for O8A … O2B). The units of $\left[\mathrm{Zn}(\mathrm{IM} 2-\mathrm{Py})_{2}\left(\mathrm{NO}_{3}\right)\right]^{+}$and uncoordinated $\mathrm{NO}_{3}{ }^{-}$anions were connected as a onedimensional chain by the intermolecular $(\mathrm{O} \cdots \mathrm{O} \cdots \mathrm{O})$ contacts (Fig. 3). To the best of our knowledge, this is the only zinc(II) complex example of the one-dimensional chain by $\mathrm{NO}_{3}{ }^{-}$anions directly contact the oxygen atoms of radicals.

\section{Acknowledgements}

This work was supported by the National Natural Science Foundation of China (No. 20471026) and the Natural Science Foundation of Henan province (No. 0311021200).

\section{References}

1. O. Kahn, Molecular Magnetism, 1993, VCH, New York.

2. A. Caneschi, D. Gatteschi, and P. Rey, Prog. Inorg. Chem., 1991, 39, 331.

3. (a) A. Caneschi, D. Gatteschi, R. Sessoli, and P. Rey, Acc. Chem. Res., 1989, 22, 392. (b) L. Y. Wang, B. Zhao, C. X. Zhang, D. Z. Liao, Z. H. Jiang, and S. P. Yan, Inorg. Chem., 2003, 42, 5804.

4. (a) E. F. Ullman, J. H. Osiecki, D. G. B. Boocock, and R. Darcy, J. Am. Chem. Soc., 1974, 94, 179. (b) E. F. Ullman, L. Call, and J. H. Osiecki, J. Org. Chem., 1970, 35, 3623.

5. Y. Yamamoto, T. Yoshida, T. Suzuki, and S. Kaizaki, Inorg. Chim. Acta, 2001, 325, 187. 